\title{
Nebulized magnesium sulphate versus nebulized salbutamol in acute bronchial asthma: a clinical trial
}

\author{
H.S. Mangat, G.A. D'Souza, M.S. Jacob
}

Nebulized magnesium sulphate versus nebulized salbutamol in acute bronchial asthma: a clinical trial. H.S. Mangat, G.A. D'Souza, M.S. Jacob. OERS Journals Ltd 1998.

ABSTRACT: Intravenous magnesium sulphate $\left(\mathrm{MgSO}_{4}\right)$ has successfully been used in the treatment of acute asthma. The present study investigated the efficacy of nebulized $\mathrm{MgSO}_{4}$ as a bronchodilator in acute asthma as compared to nebulized salbutamol.

This was a randomized, double-blind, controlled clinical trial. Asthmatics aged 1260 yrs in acute exacerbation, with a peak expiratory flow $(P E F)<300 \mathrm{~L} \cdot \mathrm{min}^{-1}$, not having taken bronchodilators and not requiring assisted ventilation were included. Patients were randomized to receive treatment with serial nebulizations of either 3 $\mathrm{mL}(3.2 \%$ solution, $95 \mathrm{mg}) \mathrm{MgSO}_{4}$ solution or $3 \mathrm{~mL}(2.5 \mathrm{mg})$ salbutamol solution. All patients were also given $100 \mathrm{mg}$ hydrocortisone $i . v$., and were monitored continuously for $2 \mathrm{~h}$ after which they were given supplemental treatment (if and when needed) and either discharged or admitted. Fischl index, PEF improvements (in \% predicted) and admission rates were the outcome variables.

Thirty-three patients were studied. Fischl score improvement was comparable and significant in both groups $\left(4.31\right.$ to 0.43 in the $\mathrm{MgSO}_{4}$ group and 4.29 to 0.76 in the salbutamol group). The increase in PEF was statistically significant and comparable in both groups (by $35 \%$ pred in the $\mathrm{MgSO}_{4}$ and by $42 \%$ pred in the salbutamol group). Two patients warranted admission in the salbutamol group and one in the $\mathrm{MgSO}_{4}$ group.

Nebulized $\mathrm{MgSO}_{4}$ had a significant bronchodilatory effect in acute asthma. This effect was not significantly different from that of nebulized salbutamol.

Eur Respir J 1998; 12: 341-344.

It is of significant concern that the death rate from asthma has stabilized and not further decreased during the last few years in most countries around the world [1]. Currently, inhaled $\beta_{2}$-adrenergic agonists are the mainstay of therapy in patients with acute asthma. Often they need to be given as frequently as every $20 \mathrm{~min}$, or even as a continuous nebulization along with steroids to achieve adequate control $[2,3]$. Theophyllines have a low therapeutic index and frequent side-effects, making them increasingly unpopular [4]. There is, therefore, a need for the assessment of newer modalities of treatment.

Numerous recent studies and case reports have described the use of intravenous magnesium sulphate $\left(\mathrm{MgSO}_{4}\right)$ to reverse bronchospasm in acute asthma [5-17]. A few studies are available on nebulized $\mathrm{MgSO}_{4}$ as a helpful agent to decrease airway resistance in bronchial challenge tests [18-20]. However, to date, no detailed, controlled clinical study is available on the efficacy of nebulized $\mathrm{MgSO}_{4}$ alone in acute asthma, in spite of favourable evidence to this effect. This randomized, double-blind, controlled study aimed to establish the efficacy of nebulized $\mathrm{MgSO}_{4}$ as a bronchodilator in the management of acute bronchial asthma.

\section{Materials and methods}

The American Thoracic Society (ATS) criteria [21] were used to classify the patients. The study was conducted at
Division of Respiratory Diseases, Dept of Medicine, St John's Medical College Hospital, St John's National Academy of Health Sciences, Koramangala, Bangalore 560034 Karnataka, India.

Correspondence: H.S. Mangat

Dept of Internal Medicine

University of Arkansas for Medical

Sciences

4301 West Markham Street

Slot 634

Little Rock

AR 72205

USA

Fax: 15016868188

Keywords: Acute asthma emergency department nebulized magnesium sulphate peak expiratory flow

Received: January 131997

Accepted after revision April 201998 the Emergency Department (ED) of St John's Medical College Hospital (St John's National Academy of Health Sciences, Bangalore, India) after approval by the Institutional Review Board and the Ethical Committee. Informed consent was obtained from all patients.

Patients included were newly diagnosed or known cases of bronchial asthma, aged 12-60 yrs, with a peak expiratory flow $(\mathrm{PEF})<300 \mathrm{~L} \cdot \mathrm{min}^{-1}$. Patients were excluded if they were febrile, had any evidence of lower respiratory tract infection, had any history or evidence of cardiac, renal or hepatic dysfunction, were pregnant, required ventilatory care, or had received oral or parenteral bronchodilators in the past $6 \mathrm{~h}$, or steroids in the past $12 \mathrm{~h}$. Because antiasthmatic medication is readily available over the counter in India, the last criterion had to be included. The most commonly used $\beta_{2}$-agonists and theophyllines in India have a 6 $\mathrm{h}$ duration of action and the steroid preparations $12 \mathrm{~h}$. This prevented the results of the study from being confounded.

All patients received an injection of hydrocortisone, $100 \mathrm{mg} i . v$., and thereafter received either four doses of nebulized $3 \mathrm{~mL}$ salbutamol $(2.5 \mathrm{mg}) 20 \mathrm{~min}$ apart (control group) or four doses of nebulized $3 \mathrm{~mL}$ (3.2\% solution, 95 mg) $\mathrm{MgSO}_{4} 20$ min apart (study group), in a randomized and double-blind fashion. A Hudson's nebulizer (Hudson Respiratory Care Inc., CA, USA) was used for the administration of the medications. This gives a mean particle size of $1.6 \pm 0.5 \mu \mathrm{m}$ and retention in the lung of $71 \pm 6 \%$ 
[22]. All patients were asked to describe any discomfort that they experienced.

The patients were monitored every $20 \mathrm{~min}$ for the first hour (the study period) and twice in the second hour (the observation period) (i.e. at 0, 20, 40, 60, 90 and $120 \mathrm{~min}$ ). The parameters monitored were: PEF, with a hand-held Wright's mini-peak flow meter, pulsus paradoxus (PP), respiratory frequency $(f \mathrm{R})$, blood pressure $(\mathrm{BP})$, cardiac frequency $(f \mathrm{C})$, clinical examination, and Fischl index [23] (at 0 and $120 \mathrm{~min}$ only). The Fischl index takes into account dyspnoea, accessory muscle use, wheeze, $f \mathrm{R}>120$ beats. $\min ^{-1}, f \mathrm{R}>30$ breaths $\cdot \mathrm{min}^{-1}, \mathrm{PP}>18 \mathrm{mmHg}$ and a PEF $<120 \mathrm{~L} \cdot \mathrm{min}^{-1}$. The presence of each scores 1 point and a total of more than 4 points implies severe asthma. The patients were monitored for hypotension, arrhythmias, loss of deep tendon reflexes and respiratory depression be-fore and after each dose was administered.

Patients whose PEF or Fischl scores did not show any improvement at the end of the $1 \mathrm{~h}$ study period were given supplemental treatment immediately, unless they were given treatment for significant distress earlier. All patients assessed at the end of $2 \mathrm{~h}$ were also given supplemental treatment, if warranted. Those patients showing marginal improvement were assessed by another physician to determine the need for admission, in order to avoid any biased opinion of the investigator. For patients requiring supplemental treatment, their status at the time of intervention was used as the end-study status for data analysis. Supplemental treatment administered consisted of salbutamol nebulization, regular doses of oral or intravenous steroids and aminophylline infusion.

The Fischl index was used rather than the PEF alone as the primary outcome measure since it includes six objective parameters that can help to define asthmatic patients' status and it is felt to be a more accurate measure of assessment than PEF alone. The PEF may not accurately reflect the degree of airway obstruction and may be confounded by factors such as patient fatigue and poor effort. However, an analysis of the PEF was also performed. The PEF measurements were also compared as a percentage of the predicted value as per the standards of the Indian population [24]. The improvements in PEF and admission rates were the other outcome measures.

The STATISTICA software package (Statsoft Inc., OK, USA) was used to calculate statistical inferences. The basal and final Fischl indices were compared by first ranking the indices and then applying the t-test for independent samples. The improvement in the Fischl index within each group was compared using the Wilcoxon paired-sample test. The improvement in the Fischl index in the two groups was compared by first ranking the improvement in the index and then applying the t-test for independent samples. The other data were analysed using analysis of variance (ANOVA) with repeated measures. A value of $p<0.05$ was taken as significant.

\section{Results}

Out of the 63 patients screened over a period of 6 months, only 33 patients met the study criteria and were included. Most of the patients not included were those who had premedicated themselves with various antiasthmatic medications. The inability of most patients to recall correctly the medication taken prevented their inclusion in order to avoid confounding the results of the study. Only single visits were considered. Patients who revisited the emergency department during the 6 months of the study were not included to avoid patient bias. There were 17 patients in the salbutamol group (controls) and 16 patients in the $\mathrm{MgSO}_{4}$ group (study group). The subjects in the two groups were comparable with respect to all demographic data (table 1) and baseline clinical data (table 2).

Of the 17 patients treated with salbutamol, two did not improve, required supplemental treatment after $60 \mathrm{~min}$ and later warranted admission (table 3). Two of the 16 patients treated with $\mathrm{MgSO}_{4}$ required supplemental therapy. One improved and was discharged, while the other required admission (table 3). The Fischl index improvement in the

Table 1. - Profile of the study population

\begin{tabular}{lcc}
\hline & \multicolumn{2}{c}{ Group } \\
\cline { 2 - 3 } & $\mathrm{MgSO}_{4}$ & Salbutamol \\
\hline Age yrs* & $33.4 \pm 10.9$ & $36.1 \pm 15.3$ \\
Sex M/F & $12 / 4$ & $11 / 6$ \\
Height cm* & $169 \pm 4$ & $164 \pm 8$ \\
Weight kg* & $58.0 \pm 9.2$ & $57.2 \pm 13.4$ \\
Atopic patients n & 12 & 8 \\
Smokers n & 5 & 1 \\
Duration yrs & 10 & 15 \\
Duration of asthma yrs & 5.5 & 7.7 \\
Newly diagnosed cases & 1 & 3 \\
\hline
\end{tabular}

*: mean \pm sD. M: male; F: female.

Table 2. - Comparison of the data before and after treatment of patients in the two groups

\begin{tabular}{|c|c|c|c|}
\hline & \multicolumn{3}{|c|}{ Group } \\
\hline & $\mathrm{MgSO}_{4}$ & Salbutamol & p-value \\
\hline \multicolumn{4}{|l|}{ PEF L·min ${ }^{-1}$} \\
\hline Basal & $166.87 \pm 61.39$ & $133.52 \pm 49.99$ & 0.096 NS \\
\hline Final & $309.37 \pm 111.26$ & $295.88 \pm 90.76$ & 0.704 NS \\
\hline p-value & $0.000 *$ & $0.000 *$ & \\
\hline \multicolumn{4}{|l|}{ PEF \% pred } \\
\hline Basal & $41.88 \pm 18.70$ & $34.35 \pm 10.59$ & 0.161 NS \\
\hline Final & $77.03 \pm 31.89$ & $76.45 \pm 22.13$ & $0.951 \mathrm{NS}$ \\
\hline p-value & $0.000^{*}$ & $0.000 *$ & \\
\hline Increase in PEF \% & $35.14 \pm 20.33$ & $44.48 \pm 20.96$ & 0.341 ns \\
\hline \multicolumn{4}{|l|}{ Fischl index } \\
\hline Basal & $4.31 \pm 1.35$ & $4.29 \pm 1.64$ & 0.762 Ns \\
\hline Final & $0.43 \pm 0.89$ & $0.76 \pm 1.25$ & $0.544 \mathrm{NS}$ \\
\hline p-value & $0.000 *$ & $0.000 *$ & \\
\hline Improvement in Fischl & $3.87 \pm 1.74$ & $3.52 \pm 1.87$ & $0.767 \mathrm{NS}$ \\
\hline Index & & & \\
\hline \multicolumn{4}{|l|}{$f \mathrm{R}$ breaths $\cdot \mathrm{min}^{-1}$} \\
\hline Basal & $31.31 \pm 6.51$ & $30.94 \pm 6.86$ & 0.874 NS \\
\hline Final & $22.87 \pm 2.82$ & $22.76 \pm 6.34$ & 0.949 NS \\
\hline p-value & $0.000 *$ & $0.000 *$ & \\
\hline \multicolumn{4}{|l|}{$f \mathrm{C}$ beats $\cdot \mathrm{min}^{-1}$} \\
\hline Basal & $112.50 \pm 12.57$ & $110.41 \pm 16.12$ & 0.682 NS \\
\hline Final & $99.37 \pm 12.01$ & $103.41 \pm 15.39$ & $0.409 \mathrm{NS}$ \\
\hline p-value & $0.006^{*}$ & 0.078 Ns & \\
\hline \multicolumn{4}{|l|}{ MAP $\mathrm{mmHg}$} \\
\hline Basal & $110.31 \pm 17.74$ & $113.29 \pm 15.89$ & 0.614 ns \\
\hline Final & $106.56 \pm 13.75$ & $104.64 \pm 12.55$ & $0.678 \mathrm{NS}$ \\
\hline $\mathrm{p}$-value & 0.251 Ns & $0.000^{*}$ & \\
\hline
\end{tabular}

Data are presented as mean \pm SD. PEF: peak expiratory flow; $f \mathrm{R}$ : respiratory frequency; $f \mathrm{c}$ : cardiac frequency; MAP: mean arterial pressure. ${ }^{*}$ : significant difference; ss: nonsignificant difference. 
Table 3. - Profile of the response and management of the patients in the two groups

\begin{tabular}{lcccc}
\hline & \multicolumn{4}{c}{ Patients $\mathrm{n}$} \\
\cline { 2 - 5 } & Enrolled & $\begin{array}{c}\text { Needing } \\
\text { no additional } \\
\text { treatment }\end{array}$ & $\begin{array}{c}\text { Needing } \\
\text { additional } \\
\text { treatment }\end{array}$ & $\begin{array}{c}\text { Warranting } \\
\text { admission }\end{array}$ \\
\hline $\mathrm{MgSO}_{4}$ & 16 & 14 & 2 & 1 \\
Salbutamol & 17 & 15 & 2 & 2 \\
\hline
\end{tabular}

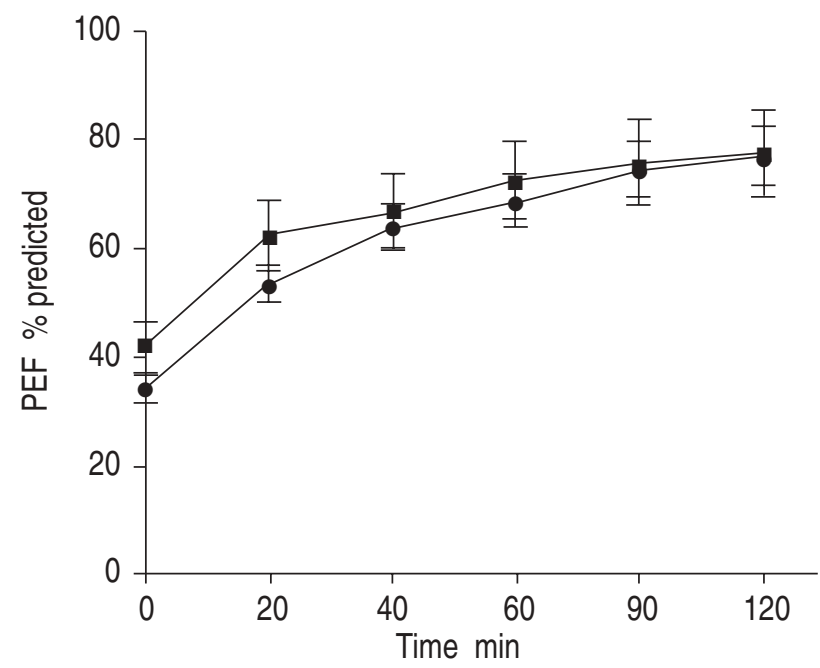

Fig. 1. - Improvement in the peak flow rates of the patients in terms of their peak expiratory flow (PEF) (in \% predicted) over the $2 \mathrm{~h}$ of the study. Data are shown as mean \pm SE. $\bullet$ : salbutamol; $\mathbf{\square}: \mathrm{MgSO}_{4}$.

$\mathrm{MgSO}_{4}$ group (4.31 to 0.43 ) was significant and similar to that seen in the salbutamol group (4.29 to 0.76) (table 2). The improvements in the PEF also shows similar improvement in the two groups with an increase by $35 \%$ pred in $\mathrm{MgSO}_{4}$ and by $42 \%$ pred in the salbutamol group $(p=0.341)$ (table 2). The mean final PEF were not significantly different between the two groups $\left(309 \mathrm{~L} \cdot \mathrm{min}^{-1}\right.$ in the $\mathrm{MgSO}_{4}$ group versus $295 \mathrm{~L} \cdot \mathrm{min}^{-1}$ in the salbutamol group) (table 2). A correction was made for the difference in the basal PEF of the two groups and there was no statistically significant difference in the final bronchodilator response $(\mathrm{p}=0.609)$. The rate of increase in the PEF of the two groups was also similar (fig. 1).

The adverse effects commonly associated with $\mathrm{MgSO}_{4}$ administration are nausea, vomiting, flushing, thirst, hypotension, drowsiness, confusion, loss of deep tendon reflexes, muscle weakness, respiratory depression and cardiac arrhythmias, which can lead to coma and cardiac arrest [25]. However, during the $2 \mathrm{~h}$ that the patients were monitored in the emergency department, only one of the patients in the $\mathrm{MgSO}_{4}$ group developed mild transient hypotension, which resolved spontaneously. A similar case of hypotension was also seen in the salbutamol group, and two patients developed fine tremors of the hand and one experienced palpitations. None of the patients in the $\mathrm{MgSO}_{4}$ group showed depressed deep tendon reflexes, which is one of the first clinical signs of magnesium toxicity.

\section{Discussion}

The results of this study show that nebulized $\mathrm{MgSO}_{4}$ has a significant bronchodilatory effect which is comparable to that of salbutamol. Two patients in the salbutamol group showed no response and warranted admission, while one patient in the $\mathrm{MgSO}_{4}$ group required admission.

Magnesium has long been thought to be a vital ion for maintaining the homeostasis of the bronchial musculature. $\mathrm{MgSO}_{4}$ is thought to act by inhibiting smooth muscle contraction [26] by facilitating calcium uptake into the sarcoplasmic reticulum [27], inhibiting the slow inward calcium current [28], and inhibiting calcium-induced calcium release [29]. It has also been suggested to inhibit histamine reease from mast cells [27] and acetylcholine release from cholinergic nerve terminals [30] and to act via a central sedative action [26].

Rosello and Pla [7] and Haury [8] conducted clinical investigations into the role of $\mathrm{MgSO}_{4}$ in asthma as early as 1936 and 1940, respectively. Since then, constant progress has been made by the multitude of studies on this subject. Notably, SковеLоFF et al. [12] demonstrated a significant increase in PEF with $\mathrm{MgSO}_{4}$ and a concomitant lower rate of admission, in a study using $1.2 \mathrm{~g}$ i.v. $\mathrm{MgSO}_{4}$ versus a placebo, in patients failing to respond to $1 \mathrm{~h}$ of $\beta_{2}$-agonist inhalational therapy. Numerous case reports [6-11] have also highlighted dramatic responses to intravenous $\mathrm{MgSO}_{4}$ in patients with acute severe asthma who were unresponsive to conventional treatment. In 1987, Rolla et al. [19] demonstrated that, in a histamine challenge test, the dose required to produce a $20 \%$ decrease in forced expiratory volume in one second (FEV1) from control values was significantly increased when the patients were pretreated with aerosolized $\mathrm{MgSO}_{4}$. In a separate study, RolLA et al. [20] observed a similar attenuation of methacholineinduced bronchoconstriction in asthmatics. In 1992, CHANDE and SKONER [18] conducted a similar trial, in which nebulized $\mathrm{MgSO}_{4}$ was administered following a bronchial challenge with methacholine. However, in this study, the authors noted no bronchodilation and concluded that nebulized $\mathrm{MgSO}_{4}$ played no role in the treatment of bronchospasm due to cholinergic stimulation. The authors explained this failure as a result of a possibly unstable nature of $\mathrm{MgSO}_{4}$ in the respiratory mucosa, a topical irritant effect, a site of action inaccessible by the inhalation route or a low-dose compared to the intravenous studies. However, the difference between the results of the two studies could be explained by the fact that $\mathrm{MgSO}_{4}$ has an inhibitory effect only on the release of acetylcholine [30] and does not have a proven anticholinergic effect on the released acetylcholine, hence the negative result of the study by CHANDE and SKONER [18].

In contrast to the above studies, in the present study, nebulized $\mathrm{MgSO}_{4}$ was used in the clinical setting of acute asthma where the provocative stimuli are multifactorial and do not act alone. In addition, serial repetitive doses of $\mathrm{MgSO}_{4}$ were used in order to administer an effective therapeutic dose, a hinderance encountered by $\mathrm{CHANDE}$ and SKONER [18]. Nebulized $\mathrm{MgSO}_{4}$ was observed to have a clinically and statistically significant bronchodilator effect. On comparison of the Fischl indices, a similar improvement was seen in both groups (table 2).

The present conclusions, therefore, differ from the opinion of CHANDE and SKONER [18], in that the inhalational 
route did not adversely affect the action of $\mathrm{MgSO}_{4}$. This is also supported by the results of RoLla et al. [20]. Nebulized $\mathrm{MgSO}_{4}$ may play a role as an adjunct to $\beta_{2}$-agonists in acute asthma, as also suggested by Вьосн et al. [17]. The low response of severe asthmatics to nebulized $\mathrm{MgSO}_{4}$ in the present study may have been due to the much lower dose used (95 mg $\times 4$ doses), compared with the higher dose used in the intravenous studies $(1.2-2 \mathrm{~g})$.

In conclusion, this study indicated that serially nebulized $\mathrm{MgSO}_{4}$ had a clinically significant bronchodilatory effect, which was not significantly different from that of salbutamol, in acute asthma. No side-effects were noted, probably owing to a greater therapeutic ratio through the inhalation route. These results suggest $\mathrm{MgSO}_{4}$ to be a feasible bronchodilator and would support the use of nebulized $\mathrm{MgSO}_{4}$ as an adjunct in the management of acute asthma. However, the optimum dose-response relationship needs to be addressed by future studies.

Acknowledgement: The authors wish to thank R. Kandavar for his help in developing the investigational protocol.

\section{References}

1. Sly RM. Stabilization of asthma mortality. Ann Allergy Asthma Immunol 1997; 78: 347-354.

2. Schuh S, Parkin P, Rajan A, et al. High versus low dose frequently administered nebulised albuterol in children with severe acute asthma. Paediatrics 1989; 83: 513-518.

3. Colacone A, Wolkove N, Stern E, et al. Continuous nebulisation of albuterol in acute asthma. Chest 1990; 97: 693-697.

4. Siegal D, Sheppard D, Gelb A, Wiinberg PF. Aminophylline increases the toxicity but not the efficacy of an inhaled beta adrenergic agonist in the treatment of acute exacerbation of asthma. Am Rev Respir Dis 1985; 132: 282-286.

5. Okayama H, Aikawa T, Okayama M, Sasaki H, Mue S, Takishima T. Bronchodilating effect of intravenous magnesium sulphate in bronchial asthma. JAMA 1987; 257: 1076-1078.

6. McNamara RM, Spivey WH, Skobeloff E, Jacubowitz S. Intravenous magnesium sulphate in the management of acute respiratory failure complicating asthma. Ann Emerg Med 1989; 18: 197-199.

7. Rosello JC, Pla JC. Sulfato de magnesio en la crisis de asma. Prensa Med Argent 1936; 23: 1677-1680.

8. Haury VG. Blood serum magnesium in bronchial asthma and its treatment by the administration of magnesium sulphate. J Lab Clin Med 1940; 26: 340-341.

9. Leber MJ, Rao S, Birrer RB. Magnesium sulphate used as an adjunct to beta-agonists in acute asthma. $J$ Emerg Med 1991; 9: 377-378.

10. Kuitert LM, Kletchko SL. Intravenous magnesium sulphate in acute life threatening asthma. Ann Emerg Med 1991; 20: 1243-1245.

11. Sydow M, Crozier TA, Zielmann S, Radke J, Burchardi $\mathrm{H}$. High-dose intravenous magnesium sulphate in the management of life threatening status asthmaticus. Intensive Care Med 1993; 19: 467-471.
12. Skobeloff EM, Spivey WH, McNamara RM, Greenspon L. Intravenous magnesium sulfate for the treatment of acute asthma in the emergency department. JAMA 1989; 262: 1210-1213.

13. Barzo P, Biro P, Liptak E, Gyurcsik A, Barzo P Jr, Szabo T. Magnezium szulfat intravenas adasa utan bekovetkezo cardiorespiratorius es elektrolit valtozasok status asthmaticusban. Orv Hetil 1993; 134 (29): 1577-1580.

14. Noppen M, Vanmaele L, Impens N, Schandevyl W. Bronchodilating effect of intravenous magnesium sulphate in acute severe bronchial asthma. Chest 1990; 97: 373-376.

15. Rolla G, Bucca C, Brussino L, Colagrande P. Effect of intravenous magnesium infusion on salbutamol-induced bronchodilatation in patients with asthma. Magnes Res 1994; 7: 129-133.

16. Schiermeyer RP, Finkelstein JA. Rapid infusion of magnesium sulphate obviates need for intubation in status asthmaticus. Am J Emerg Med 1994; 12: 164-166.

17. Bloch H, Silverman R, Mancherje N, et al. Intravenous magnesium sulphate as an adjunct in the treatment of acute asthma. Chest 1995; 107: 1576-1581.

18. Chande VT, Skoner DP. A trial of nebulised magnesium sulphate to reverse bronchospasm in asthmatic patients. Ann Emerg Med 1992; 21: 1111-1115.

19. Rolla G, Bucca C, Bugiani M, Arossa W, Spinaci S. Reduction of histamine-induced bronchoconstriction by magnesium in asthmatic subjects. Allergy 1987; 42: 186188.

20. Rolla G, Bucca C, Arossa W, Bugiani M. Magnesium attenuates methacholine induced bronchoconstriction in asthmatics. Magnesium 1987; 6: 201-204.

21. American Thoracic Society. Standards for the diagnosis and care of patients with chronic obstructive pulmonary disease (COPD) and asthma. Am Rev Respir Dis 1987; 136: 225-244.

22. Cropp GTM, Berntein JL, Boushey HH, et al. Guidelines for bronchial inhalation challenges with pharmacological and antigenic agents. ATS News, Spring 1980; pp. 11-19.

23. Fischl M, Pitchenik A, Gardner LB. An index predicting relapse and need for hospitalisation in patients with acute bronchial asthma. N Engl J Med 1981; 305: 783-789.

24. Jindal SK, Bansal S, Malik SK. Peak expiratory flow rate in healthy north Indian adults. Bull PGI 1974; 8: 2.

25. Martindale W. Magnesium Sulphate: Adverse Effects. The Extra Pharmacopoeia, 29th edn. London, The Pharmaceutical Press, 1989; p. 1033.

26. Altura BM, Altura BT, Carella A. Magnesium deficiency induced spasms of umbilical vessels: relation to preeclampsia, hypertension, growth retardation. Science 1983; 221: 376-378.

27. Bois P. Effect of magnesium deficiency on mast cells and urinary histamine in rats. Br J Exp Pathol 1963; 44: 151155.

28. Kass RS, Lederer WJ, Tsin RW, et al. Role of calcium ions in transient inward currents and after contractions induced by strophanthidin in cardiac Purkinjee fibres. $J$ Physiol 1978; 281: 187-208.

29. Dunnet J, Naylen WG. Calcium efflux from cardiac sarcoplasmic reticulum: effects of calcium and magnesium. J Mol Cell Cardiol 1978; 10: 487-498.

30. Del Castillo J, Engback L. The nature of the neuromuscular block produced by magnesium. J Physiol 1954; 124 : 370-384. 